\title{
Efficiency Response of Vermicompost and Vermitea Levels on Growth and Yield of Eggplant (Solanum melongena, L.)
}

\author{
Amal K. Abou El- Goud ${ }^{1}$
}

\begin{abstract}
This present aimed to convert chicken manure and kitchen wastes into vermicompost, which riches not only in macro (N, P, K) and micro (Ca, Mg, Fe, Zn, Mn) nutrients, but also phytohormones, antibiotics, different beneficial microbes and enzymes by red wiggler (Eisenia fetida). As well as use vermicompost at two levels (high $=6.5$ and low $=3.5 \mathrm{t} /$ fed.) with 3,4 times and without of vermitea soil irrigated to increase the yield and quality of eggplant "cv. Black beauty" and may be a suitable replacement for chemical fertilizers. Each treatment had 3 replicates with 27 plants (9 plants/ plot) and RCBD were statistical analyzed. Effect of the treatments on the vegetation parameters, total yield and fruit quality of eggplant were determined. Investigation results cleared that, the application of high rate $(6.5 \mathrm{t} / \mathrm{fed}$.) of vermicast + organic liquid (vermitea) 4 times as a soil drench lead to significantly increased on vegetative parameters e.g. plant height $(157.67 \mathrm{~cm}$. /plant), no. leaves/plant $(141.6)$, no. of branches (9/plant), leaf area index (0.28), total cholorophyll (48.3 SPAD in leaves), no. of flowers (4.67/plant), no. of fruits/plant (4.67), fruit length and diameter (14.53 and $24.5 \mathrm{~cm}$., respectively) and shoot dry weight $(1511.2 \mathrm{~g} / \mathrm{plant})$ as an average of both sites compared to control plant. Quality nutritional status of eggplant fruits and green shoots biomass by using the high rate of vermicast (6.5t/fed.) + Vermitea (4 times) as an organic liquid on soil drenches (T1) more than other treatments. Significant increases in $N(\mathbf{1 . 6 8}), P(0.39)$ and $\mathrm{K}(3.45 \mathrm{mg} / \mathrm{g})$ uptake of shoots, as an average of both sites at $\mathrm{T} 1$, but the lowest significant means were $(0.88,0.21$ and $1.81 \mathrm{mg} / \mathrm{g}$ ) of NPK uptake in shoots in the treated plants with $\mathrm{R} 100 \%$ of NPK chemical fertilizers. T1 $=$ high rate (6.5t/fed.) of vermicompost + fourth soil drench of vermitea gave the highest values in the chemical components of fruits. Significant increases of the percentage of $\mathrm{N}(3.5), P(0.40), K(2.1)$ and the highest significant amount of anthocyanin was $516.7 \mathrm{mg} / \mathrm{g}$ in fruits by treated plants with $\mathrm{T} 1$. Although, the lowest significant means were $(1.8,0.21$ and $1.4 \%$ ) of fruits at T7 (=the recommended doses of NPK chemical fertilizers). As well as, this article revealed that, the high concentrations of vermicast and vermitea must be for improving plant health, protection growth and provides the optimum eggplant production.
\end{abstract}

Key words: vermicompost, vermitea, earthworm (Eisenia fetida), eggplant.

DOI: 10.21608 /ASEJAIQJSAE.2020.76559

${ }^{1}$ Department of Botany (Organic Agriculture), Agricultural Faculty,

Damietta University, Egypt

E-mail: amalgoud08@gmail.com

Received January 01, 2020, Accepted March 09, 2020

\section{INTRODUCTION}

Eggplant "Solanum melongena, L." shows a wide range of shapes, colors (white, yellow, green, purple pigmentation to black). It is an economically important crop in Africa and also cultivated in warm temperate regions of the Mediterranean. Eggplant fruits riche of minerals $(\mathrm{K}, \mathrm{Mn}, \mathrm{Fe}$ and $\mathrm{Ca}$ ), vitamins for human health and it is low in calories, not only is used as cooking vegetable but also it has many medical values; which is help to lower the blood cholesterol levels, regulate high blood pressure and suitable for diet and diabetic (Gandhi and Sundari, 2012, Belliturk et al., 2017 and Al Ali et al., 2019).

Vermicompost is riches with macro ( $\mathrm{N}, \mathrm{P}$ and $\mathrm{K}$ ), micro (Fe, $\mathrm{Mn}, \mathrm{Mg}, \mathrm{Zn}$ ) nutrients, beneficial soil microbes; e.g. actinomycetes, nitrogen fixing bacteria" Azotobacter and Azosperillium, Nitrobacter and Rhizobium", phosphate solubilizing bacteria, Pseudomonas sp., Trichoderma were ranging $10^{-2}-10^{-6}$ (Sinha et al., 2010; Singhei et al., 2011 and Belliturk et al., 2017). They have potential to inhibit pathogens, not only it used as bio and organic -fertilizers, but also used as bio-pesticides (Singh et al., 2012 and Pyia et al., 2018). It is provides all necessary elements for a good plant nutritional, enhance its uptake of nutrients of $\mathrm{N}$, $\mathrm{P}, \mathrm{K}, \mathrm{Ca}$, and $\mathrm{Mg}$ in roots and shoots system with a humic acids, which is derived them from vermicompost to increase nutrients content in plant body (Kumar, 2005; Singh et al., 2008 and Singh and Hussain, 2015). It is riches with plant growth regulators like cytokinins, gibberellins, auxins and idol 3 acetic acid. So that, it used for plant growth promoting and biological control by antagonistic ability against soil bore pathogens for plant protection (Arancon et al., 2008; Adeleke et al., 2015; Musa et al., 2017 and Al Ali et al., 2019). It is a soil microbial friendly, has digestive enzymes e.g. chitinases, lipases, cellulases, urases, phosphatases and dehydrogenases; which are secreted from intestine of earthworms and ingested microorganisms; (Sundararasu and Jeyasankar, 2014 and Musa et al., 2017). It also improved soil structure, reduce soil erosion, increase its physiochemical (soil texture, $\mathrm{pH}$, soil aggregation, E.C., bulk density, organic matter, water holding capacity and biological properties e.g. enzymes and microbial 
population (Piya et al., 2018). Vermicompost is as (organic fertilizer + biofertilizer + biopesticides), lead to organic agricultural system, which is a sustainable alternative to conventional system for environmental protection (Bellitürk, 2018 ; Piya et al., 2018 and Al Ali et al., 2019 and Soraya et al., 2020).

Vermitea is successfully used in raising crop productivity, maintain good quality of vegetables. It has positive effects in soil quality, productivity and enhanced the soil microbiology (Musa et al., 2017 and Piya et al., 2018). Vermitea is extract from vermicast for efficiency production, economically and environmentally suitable (Sundararasu and Jeyasankar, 2014). It has an important component of Integrated Plant Nutrition System (IPNS), which plays an important role for plant growth, rooting initiation, promoting growth rates of shoots and roots and improve crop production (Baniya and Vaidya, 2011 and Sundararasu and Jeyasankar, 2014 and Soraya et al., 2020). It is lead to increase the soil organic matter, macro and micro- nutrients for enhancement the soil quality and beneficial soil microbiology serving as biofertilizers and biopesticides. Vermitea as liquid manure for excellent plant growth promoting, enhances microbial diversity, enzymatic activity (lipases, chitinases and cellulases), which are secreted from earthworm intestine (Brown, 1995 and Musa et al., 2017). It regulates the diversity of nematode in soil and provides as biological control of plant and soil pathogens by Actinomycetes, Streptomyces, Trichoderma spp. and Pseudomonas spp., were isolated from them (Arancon et al., 2003 ; Aira et al., 2006; Nath et al., 2011 and Baniya and Vaidya, 2011; Adhikary, 2012 and Alidadi et al., 2014 and Soraya et al., 2020).

This investigation target to use the high concentrations of vermicompost and vermitea to enhance eggplant productivity.

\section{MATERIALS AND METHODS}

Two field experiments carried out in Faculty of Agriculture (Saba-Basha), Alexandria University; at 15 th, June in 2018 (in two different sites). Sample of experimental soil surface layer $(0-30 \mathrm{~cm})$ was analyzed before sowing; the physico-chemical characteristics of soil $[\mathrm{pH}=7.6$, O.M. $\%=0.36 \%$, available of $\mathrm{N}=115.7$ $\mathrm{mg} / \mathrm{kg}, \mathrm{P}=27.5 \mathrm{mg} / \mathrm{kg}$ and $\mathrm{K}=475 \mathrm{mg} / \mathrm{kg}$, E.C. $(1: 1$ water extract $)=0.37 \mathrm{ds} / \mathrm{m}$ and $\left.\mathrm{CaCO}_{3} \%=28 \%\right]$. Soil texture was sand $(54.9 \%)$, clay $(19.9 \%)$ and loam $(24.9 \%)$.As well as physico-chemical contents of vermicompost and vermitea samples were taken before adding to the soil and determined (total organic matter $\%=22.29 \%$, organic carbon $\%=12.93 \%, \mathrm{C} / \mathrm{N}$ ratio $=1: 13, \mathrm{pH}=8.3$ and 7.9 , E.C. $=1.97$ and $2.3 \mathrm{dS} / \mathrm{m}$ , total amount of macro elements $; \mathrm{N}=1$ and $1.5 \%, \mathrm{P}=$
1.63 and $2.0 \%$ and $\mathrm{K}=0.66$ and $0.96 \%$, respectively ) according to Jackson, 1973; Evenhuis, 1978; Chapman and Pratt, 1978; Lowther, 1980; Page et al., 1982 and Klute 1986. Total plot area was $3.5 \mathrm{~m}$ length and $0.80 \mathrm{~m}$ width and $33 \mathrm{~cm}$. distance between two hills. It contains 9 plants per plot (replicate $=$ the experimental unit). Seven treatments with 3 replicates/ treatment (27 plants / treatment) were laid out in RCBD (Randomized Complete Block Design). The following treatments schedule: $\mathrm{T} 1=$ Vemicompost at high rate $(6.5 \mathrm{t} / \mathrm{fed})+$. vermitea as soil drench ( 4 times), $\mathrm{T} 2=$ Vemicompost at high rate $(6.5 \mathrm{t} / \mathrm{fed}$.) +vermitea as soil drench (3 times), $\mathrm{T} 3=$ Vemicompost at high rate $(6.5 \mathrm{t} / \mathrm{fed}$.), T4= Vemicompost at low rate $(3.5 \mathrm{t} / \mathrm{fed}$.) + vermitea as soil drench (4 times), T5 $=$ Vemicompost at low rate $(3.5$ t/fed.) + vermitea as soil drench (3 times), T6= Vemicompost at low rate $(3.5 \mathrm{t} / \mathrm{fed}$.) and $\mathrm{T} 7=$ Control (the recommended doses of chemical fertilizers; $\mathrm{N}=$ Ammonium Nitrate $=33.5 \%$ ( $350 \mathrm{~kg} / \mathrm{fed}$.), $\mathrm{P}=$ Super Calcium Phosphate $=15.5 \%(300 \mathrm{~kg} / \mathrm{fed}$.$) and \mathrm{K}=$ Potassium Sulphate $=48 \%(200 \mathrm{~kg} / \mathrm{fed}$. $)$.

Vermitea was produced by soaked in rain water with volume 1:10 for two days and it was sieved through a 2 $\mathrm{mm}$ sieve to produce vermitea (Sundararasu and Jeyasankar, 2014 and Chaulagain et al., 2017).

Vermicompost was done by 400 earthworms different species of epigeic but the most of kind "Eisenia fetida "in a worm bin $(90 \mathrm{~cm}$ length, $50 \mathrm{~cm}$ width and $40 \mathrm{~cm}$ height). Earthworms were obtained from mud soil. Chicken manure, azolla and kitchen wastes were inoculated with 'Eisenia fetida' and newspaper stripes to maintain the moisture $50 \%$ for earthworms and metabolic activities (Politud and Pabellan, 2016; Musa et al., 2017 and Piya et al., 2018).

Eggplant " Solanum melongena, L." seeds of species cv. Black beauty; were sown at $15^{\text {th }}$ June 2018 ; in the nursery bed; which was filled with the mixture of sandy clay soil: vermicompost: peatmos, by $6: 1.5: 2$; respectively with $0.5 \%$ of humic acid powder and watered. After 21 days, the seedlings were obtained and becarefully transplanted into the open field experiments and they were irrigated every 2 or 3 days by dripirrigation system. Weeds were controlled by handhowling once every 10 days after transplanting to increase the defense of the plants against the insects in addition to cover eggplant under white net for a good protection. Fruit harvesting is beginning after 21 days from transplanting date $7^{\text {th }}$ July for 13 weeks (cutting is every 5 days) and total number of cuttings were 18 cuttings during the period of harvest. In order to collect the total yield from the early yield, which was expressed as the sum of fruit weight of the first two pickings and total yield $(\mathrm{kg} / \mathrm{fed}$.) was calculated from the first two pickings up to the end harvesting continued from $28^{\text {th }}$ 
July to $5^{\text {th }}$ November. Randomized three plants were taken from each experimental unit (plot) to determine eggplant growth parameters [plant height $(\mathrm{cm})$, number of leaves/ plant, number of branches/plant, number of flowers/plant, shoot dry weight g/plant] were recorded at the end of the growing season. According to Roods and Blood-Worth (1964) were measured total chlorophyll in leaves (SPAD), Signal Passed At Danger, which is a lightweight handheld for measuring the chlorophyll content of leaves without causing damage to plant, at a green stage and leaf area index $\left(\mathrm{cm}^{2}\right)$. Fruiting parameters like number of fruits/plant, fruit length and diameter $\mathrm{cm}$ were measured during the harvesting period. Samples of eggplants (leaves and fruits) were washed by tap water then by distilled water and oven dried at $75^{\circ} \mathrm{C}$ for fixing dry weights (72h.) to determine some chemical components. Dried samples of leaves and fruits were finely ground, then wet digested by using concentrate of $\mathrm{H}_{2} \mathrm{SO}_{4} / \mathrm{H}_{2} \mathrm{O}_{2}$ according to Lowther, 1980 to determine the percentage of phosphorus (vanaomoly-bdophosphoric method), potassium (flam photometer), both of them according to Jackson, 1973. Total nitrogen was determined by Nessler's method (Chapman and Pratt, 1978) in leaves and fruits. Anthocyanin (mg/100g fresh weight) in fruits was measured at the stage of coloration according to (Rabino et.al., 1977). All data were statistically analyzed using the SAS program (SAS, 2001) and means of seven treatments were compared using Duncan's Multiple Range test at 5\% level of probability in this investigation.

\section{RESULTS AND DISCUSSION}

Available of N, P and $\mathrm{K}$ the experimental soil were $115.7,27.5$ and $475 \mathrm{mg} / \mathrm{kg}$, respectively; which they below the range of requirement external application of macro-nutrients for a good plant growth, yield and fruit quality (Landon, 1991). Organic fertilizers (vermicompost and vermitea) were analyzed and results showed that; they lead to increase the total amounts of $\mathrm{N}, \mathrm{P}$ and $\mathrm{K}$ (1, 1.63 and $0.66 \%$; respectively) in vermicompost and $(1.5,2$ and $0.96 \%$ respectively) in vermitea for requirement range to eggplant growth and protect, also.

\section{Vegetative growth and total yield characters}

Eggplant "cv. Black beauty" beginning the fruiting stage 40 days after planting ( $15^{\text {th }}$ June); it was harvested 18 times; the first harvest was in $28^{\text {th }}$ July and the last harvest was in $5^{\text {th }}$ November, 2018. Tables 1 and 2, the means showed that vermicompost, vermitea and their combinations between them lead to significant increases in all morphological characters as compared to control treatment. The highest eggplant height (159.0 and $156.3 \mathrm{~cm})$, No. of leaves/plant (142.0 and 141.17), leaf area index $\left(0.28 \mathrm{~cm}^{2}\right)$, total cholorophyll in leaves (48.
03 and 48.63), No. of branches/plant (9.3 and 8.67) and shoot dry weight (1492.3 and $1530.0 \mathrm{~g} / \mathrm{plant})$; in both sites; respectively, were significantly increased by the high rate of vermicompost $6.5 \mathrm{t} / \mathrm{fed}$. and 4 times of vermitea as soil drench more than other organic treatments compared to control plant. However the lowest means of plant height $(79.33$ and $79.9 \mathrm{~cm})$, No. of leaves/plant (74.5 and 74.5), leaf area index (0.14), total cholorophyll in leaves (25.37 and 26.07) and shoot dry weight (789.3 and $783.3 \mathrm{~g} / \mathrm{plant}$ ) in both sites, respectively were recorded with control treatment. It was clear that, the high rate $6.5 \mathrm{t} / \mathrm{fed}$. of vermicompost with 4 times of vermitea as a soil drench during growing season resulted in considerable significantly increased on plant biomass, productivity of fruits and healthy vegetation parameters including; No. of fruits/plant (4.67), fruit length $(14.5 \mathrm{~cm})$ and diameter $(24.5 \mathrm{~cm})$ and No. of flowers/ plant (4.67), as an average in both sites. Furthermore they improve soil aeration, this might explain the consistent increase in fruit number, fruit weight and fruit length by application of vermicast and vermitea. Vermitea can be economically, productivity suitable for healthy plant growth, increased the fruit quality, yield and for enhancement the soil environment (Gandhi and Sundari, 2012; Sundararasu and Jeyasankar, 2014 and Belliturk et al., 2017 and Soraya et al., 2020).These reported that, significant increases in growth and yield of treated plants with vermitea, due to high available amounts of macro and micro- elements in vermitea. Positive effect of vermicompost at $5 \mathrm{t} / \mathrm{ha}$ either or combination with FYM or chemical fertilizers lead to enhance the vegetation, flowering, fruiting stage, total yield and food quality of eggplants (Seethalakshmi,2011 and Chaulagain et al.,2017 and Bellitürk, 2018). Similarly, Al Ali et al. (2019), reported that organic fertilizers e.g. vermicompost can be significant suitable replacement for chemicals, which are competitive for environmental pollution prevent. Results in Table (2) recorded that, the highest significant of total yield were $470.6 \mathrm{~kg} / \mathrm{fed}$ as an average in both sites, at $6.5 \mathrm{t} / \mathrm{fed}$. of vermicompost and four times of vermitea as a soil drench compared to controlled plant $(248.2 \mathrm{~kg} / \mathrm{fed}$.). This investigation revealed, there are significantly differences between other organic treatments (T1, T2, T3, T4, T5, and T6) in fruit yield (kg/fed.). Singh Ahirwar and Hussain (2015), prepared and reported the vermicompost contains highly significant quantities of nutrients, beneficial microbes biologically active metabolites, cytokines, gibberellins, auxins and group B vitamins, so as to get better healthy food and quality of diverse plants. Significant accumulation of N, P, K, Mn, $\mathrm{Mg}, \mathrm{Ca}$ and $\mathrm{Zn}$ in roots system with application of humic acids derived from vermicompost and its tea (Adeleke et al., 2015 and Chaulagain et al., 2017). 
Table 1. Effect of vermicompost and vermitea levels on some vegetative growth characters of black eggplant " Solanum melongena, $L^{\prime \prime}$ cv. Black beauty; in two sites, 2018

\begin{tabular}{|c|c|c|c|c|c|c|c|c|c|c|c|c|}
\hline \multirow[t]{2}{*}{$\mathbf{T}$} & \multicolumn{2}{|c|}{$\begin{array}{l}\text { Plant height } \\
\text { (cm) }\end{array}$} & \multicolumn{2}{|c|}{$\begin{array}{c}\text { No. of leaves/ } \\
\text { plant }\end{array}$} & \multicolumn{2}{|c|}{$\begin{array}{c}\text { No. of } \\
\text { branches/plant }\end{array}$} & \multicolumn{2}{|c|}{$\begin{array}{l}\text { Leave area } \\
\text { index }\left(\mathrm{cm}^{2}\right)\end{array}$} & \multicolumn{2}{|c|}{$\begin{array}{c}\text { Shoot dry weight } \\
\text { (g/plant) }\end{array}$} & \multicolumn{2}{|c|}{$\begin{array}{l}\text { Total Chlorophyll } \\
\text { (SPAD) in leaves }\end{array}$} \\
\hline & Site 1 & Site 2 & Site 1 & Site 2 & Site 1 & Site 2 & Site 1 & Site 2 & Site 2 & Site1 & Site 2 & Site1 \\
\hline $\mathrm{T} 1$ & $159.0^{\mathrm{a}}$ & $156.33^{a}$ & $142.0^{\mathrm{a}}$ & $141.17^{\mathrm{a}}$ & $9.33^{\mathrm{a}}$ & $8.67^{\mathrm{a}}$ & $0.28^{\mathrm{a}}$ & $0.28^{\mathrm{a}}$ & $1530.0 \mathrm{a}$ & $1492.3 \mathrm{a}$ & $48.03 a$ & $48.63 a$ \\
\hline $\mathrm{T} 2$ & $141.33^{\mathrm{b}}$ & $139.0^{\mathrm{b}}$ & $127.67^{b}$ & $128.0^{\mathrm{b}}$ & $7.67^{b}$ & $7.67^{b}$ & $0.25^{\mathrm{b}}$ & $0.24^{b}$ & $1330.0 \mathrm{~b}$ & $1350.0 \mathrm{~b}$ & $44.23 b$ & $34.97 \mathrm{~b}$ \\
\hline $\mathrm{T} 3$ & $127.0^{\mathrm{c}}$ & $127.0^{\mathrm{c}}$ & $115.0^{\mathrm{c}}$ & $115.33^{\mathrm{c}}$ & $7.0^{\mathrm{c}}$ & $6.67^{\mathrm{c}}$ & $0.22^{c}$ & $0.22^{\mathrm{c}}$ & $1216.7 \mathrm{c}$ & $1201.7 \mathrm{c}$ & $39.6 \mathrm{c}$ & $39.43 c$ \\
\hline $\mathrm{T} 4$ & $113.54^{\mathrm{d}}$ & $114.27^{\mathrm{d}}$ & $102.83^{\mathrm{d}}$ & $102.73^{\mathrm{d}}$ & $5.67^{d}$ & $5.33^{d}$ & $0.20^{d}$ & $0.21^{\mathrm{d}}$ & $1080.0 \mathrm{~d}$ & $1063.3 d$ & $35.2 \mathrm{~d}$ & $35.07 \mathrm{~d}$ \\
\hline T5 & $102.0^{\mathrm{e}}$ & $101.0^{\mathrm{e}}$ & $93.07^{\mathrm{e}}$ & $93.43^{\mathrm{e}}$ & $4.33^{\mathrm{e}}$ & $4.67 \mathrm{de}$ & $0.18^{\mathrm{e}}$ & $0.17^{\mathrm{e}}$ & $990.7 \mathrm{e}$ & $951.7 \mathrm{e}$ & $32.03 \mathrm{e}$ & $32.07 \mathrm{e}$ \\
\hline T6 & $92.0^{f}$ & $91.0^{\mathrm{f}}$ & $83.23^{\mathrm{f}}$ & $83.83^{f}$ & $4.33^{f}$ & $4.0^{\text {ef }}$ & $0.16^{\mathrm{f}}$ & $0.17^{\mathrm{e}}$ & $870.0 \mathrm{f}$ & $880.7 \mathrm{f}$ & 29.0f & $29.27 f$ \\
\hline $\mathrm{T} 7$ & $79.33^{\mathrm{g}}$ & $79.9^{\mathrm{g}}$ & $74.50^{\mathrm{g}}$ & $74.4^{\mathrm{g}}$ & $3.67^{\mathrm{g}}$ & $3.33^{f}$ & $0.14^{\mathrm{g}}$ & $0.14^{\mathrm{f}}$ & $783.3 \mathrm{~g}$ & $689.3 \mathrm{~g}$ & $25.37 \mathrm{~g}$ & $26.07 \mathrm{~g}$ \\
\hline
\end{tabular}

$\mathrm{T} 1$ (vermicast $6.5 \mathrm{t} / \mathrm{fed}$ + + vermitea 4 times); T2 (vermicast $6.5 \mathrm{t} / \mathrm{fed}$. + vermitea 3 times); T3= (Vermicast $6.5 \mathrm{t} / \mathrm{fed}$ ); $\mathrm{T} 4$ (Vermicast 3.5 t/fed. + vermitea 4 times); T5 (Vermicast 3.5 t/fed. + vermitea 3 times); T6 (Vermicast 3.5 t/fed.) and T7 (Control $=\mathrm{R}_{100 \%}$ of chemical $\mathrm{N}, \mathrm{P}$ and $\mathrm{K}$ fertilizers)

Table 2. Effect of vermicompost and vermitea levels on total yield characters of black eggplant "Solanum melongena, $L "$ cv. Black beauty; in two sites, 2018

\begin{tabular}{|c|c|c|c|c|c|c|c|c|c|c|}
\hline \multirow[t]{2}{*}{ Treat. } & \multicolumn{2}{|c|}{ No. of flowers/ plant } & \multicolumn{2}{|c|}{$\begin{array}{c}\text { No. of fruits / } \\
\text { plant }\end{array}$} & \multicolumn{2}{|c|}{ Fruit length (cm.) } & \multicolumn{2}{|c|}{ Fruit diameter (cm.) } & \multicolumn{2}{|c|}{ Total yield (kg/fed.) } \\
\hline & Site1 & Site 2 & Site1 & Site 2 & Site1 & Site 2 & Site1 & Site 2 & Site1 & Site 2 \\
\hline $\mathrm{T} 1$ & $4.67 \mathrm{a}$ & $4.67 \mathrm{a}$ & $4.67 \mathrm{a}$ & $4.67 \mathrm{a}$ & $14.5 \mathrm{a}$ & $14.53 \mathrm{a}$ & $24.43 \mathrm{a}$ & $24.53 \mathrm{a}$ & $470.58 \mathrm{a}$ & $470.50 \mathrm{a}$ \\
\hline $\mathrm{T} 2$ & $4.33 \mathrm{ab}$ & $4.33 \mathrm{a}$ & $4.0 \mathrm{ab}$ & $4.67 \mathrm{a}$ & $13.1 \mathrm{~b}$ & $13.0 \mathrm{~b}$ & $21.73 b$ & $21.77 b$ & $421.30 \mathrm{~b}$ & $421.90 b$ \\
\hline $\mathrm{T} 3$ & $3.67 \mathrm{bc}$ & $3.67 \mathrm{ab}$ & $3.67 b$ & $3.33 \mathrm{~b}$ & $11.6 \mathrm{c}$ & $11.9 \mathrm{c}$ & $19.77 \mathrm{c}$ & $19.8 \mathrm{c}$ & $381.35 \mathrm{c}$ & $381.20 \mathrm{c}$ \\
\hline $\mathrm{T} 4$ & $3.33 \mathrm{~cd}$ & $3.67 \mathrm{ab}$ & $2.67 \mathrm{c}$ & $2.33 b c$ & $10.5 \mathrm{~d}$ & $10.7 d$ & $17.7 \mathrm{~d}$ & $17.4 \mathrm{~d}$ & $343.38 d$ & $343.54 d$ \\
\hline T5 & $2.67 \mathrm{~d}$ & $2.67 b c$ & $2.0 \mathrm{c}$ & $1.67 \mathrm{c}$ & $9.5 \mathrm{e}$ & $9.5 \mathrm{e}$ & $15.57 \mathrm{e}$ & $15.73 \mathrm{e}$ & $308.92 \mathrm{e}$ & $308.30 \mathrm{e}$ \\
\hline T6 & $1.67 \mathrm{e}$ & $1.67 \mathrm{~cd}$ & $1.0 \mathrm{~d}$ & $1.67 \mathrm{c}$ & $8.5 \mathrm{f}$ & $8.7 f$ & $14.33 \mathrm{f}$ & $14.47 \mathrm{f}$ & $281.59 f$ & $281.38 f$ \\
\hline $\mathrm{T} 7$ & $0.67 f$ & $1.0 \mathrm{~d}$ & $1.0 \mathrm{~d}$ & $1.67 \mathrm{c}$ & $7.7 \mathrm{~g}$ & $7.7 \mathrm{~g}$ & $12.67 \mathrm{~g}$ & $12.77 \mathrm{~g}$ & $248.10 \mathrm{~g}$ & $247.7 \mathrm{~g}$ \\
\hline
\end{tabular}

T1 (vermicast 6.5 t/fed. + vermitea 4 times); T2 (vermicast 6.5 t/fed. + vermitea 3 times); T3= (Vermicast 6.5 t/fed.); T4 (Vermicast 3.5 t/fed. + vermitea 4 times); T5 (Vermicast 3.5 t/fed. + vermitea 3 times); T6 (Vermicast 3.5 t/fed.) and T7 (Control $=\mathrm{R}_{100 \%}$ of chemical $\mathrm{N}, \mathrm{P}$ and $\mathrm{K}$ fertilizers)

\section{Chemical composition in shoots and fruits}

According to the results of variance analysis to determine impact the high rate of vermicompost and liquid organic fertilizer (vermitea) on the healthy growth eggplant and fruits quality was conducted in Table (3). Data presented in Table (3), showed that N, P and $\mathrm{K}$ uptake $(1.68,0.39$ and $3.46 \mathrm{mg} / \mathrm{kg}$ as an average of two sites, respectively) in shoots were highly significant increases by the application of $6.5 \mathrm{t} / \mathrm{fed}$. of vermicompost and 4 times soil drench of vermitea more than other organic treatments compared to control once. This investigation results (Table, 3) were reported that the significant lowest means in shoot $\mathrm{N}, \mathrm{P}$ and $\mathrm{K}$ uptakes $(0.88,0.21$ and $1.82 \mathrm{mg} / \mathrm{kg}$ as an average of both sites, respectively) in treated plants with the recommended doses of NPK chemical fertilizers compared to other organic treatments. These results can be explained that organic substances from vermicompost and vermitea, which are rich in humus, macro ( $\mathrm{N}, \mathrm{P}$ and $\mathrm{K}$ ) and micronutrients, also having beneficial soil microflora and huge plant growth regulators. They play vital roles in building soil fertility, vigor healthy plant growth and valuable food products contain essential elements, vitamins and active components of microbial mass (Moraditochaee et al., 2011; Adeleke et al., 2015; Musa et al., 2017; Chaulagain et al., 2017 and Al Ali et al., 2019 and Soraya et al., 2020). Data in Table (3) conducted that, the significant differences between seven treatments in shoot $\mathrm{N}, \mathrm{P}$ and $\mathrm{K}$ uptakes $(\mathrm{mg} / \mathrm{kg})$ and the percentage of $\mathrm{N}, \mathrm{P}$ and $\mathrm{K}$ in black eggplant fruits. Significant increases in $\mathrm{N}$ (3.5 and 3.49\%), P (0.40\%) and K (2.07 and $2.1 \%$ in fruits) in both sites, respectively with high 
Table 3. Effect of vermicompost and vermitea levels on chemical components in shoots and fruits of black eggplant " Solanum melongena, L" cv. Black beauty; in two sites (2018)

\begin{tabular}{|c|c|c|c|c|c|c|c|c|c|c|c|c|c|c|}
\hline \multirow[t]{2}{*}{ T. } & \multicolumn{2}{|c|}{$\begin{array}{l}\text { N uptake in } \\
\text { shoots }\end{array}$} & \multicolumn{2}{|c|}{$\begin{array}{l}\text { P uptake in } \\
\text { shoots }\end{array}$} & \multicolumn{2}{|c|}{$\begin{array}{l}\text { K uptake in } \\
\text { shoots }\end{array}$} & \multicolumn{2}{|c|}{$\mathbf{N} \%$ in fruits } & \multicolumn{2}{|c|}{$P \%$ in fruits } & \multicolumn{2}{|c|}{$\mathrm{K} \%$ in fruits } & \multicolumn{2}{|c|}{$\begin{array}{l}\text { Anthocyanine } \\
\text { (mg/g) in fruits }\end{array}$} \\
\hline & Site1 & Site 2 & Site1 & Site 2 & Site1 & Site 2 & & & & & & & Site1 & Site2 \\
\hline $\mathrm{T} 1$ & & & & & & & & & & & & & & \\
\hline $\mathrm{T} 2$ & & & & & & & & & & & & & & \\
\hline $\mathrm{T} 3$ & & & & & & & & & & & & & & \\
\hline $\mathrm{T} 4$ & & & & & & & & & & & & & & \\
\hline $\mathrm{T} 5$ & & & & & & & & & & & & & & $338.8 \mathrm{e}$ \\
\hline T6 & $0.99 \mathrm{f}$ & $1.98 \mathrm{e}$ & $0.23 \mathrm{f}$ & $0.23 \mathrm{f}$ & $2.07 f$ & $2.05 f$ & $2.04 \mathrm{f}$ & $2.03 \mathrm{f}$ & $0.24 \mathrm{f}$ & $0.24 \mathrm{f}$ & $1.21 \mathrm{f}$ & $1.20 \mathrm{f}$ & $304.60 f$ & $304.7 f$ \\
\hline $\mathrm{T} 7$ & $0.88 \mathrm{~g}$ & $0.88 \mathrm{f}$ & $0.21 \mathrm{~g}$ & $0.21 \mathrm{~g}$ & $1.81 \mathrm{~g}$ & $1.81 \mathrm{~g}$ & $1.80 \mathrm{~g}$ & $1.83 \mathrm{~g}$ & $0.21 \mathrm{~g}$ & $0.21 \mathrm{~g}$ & $1.09 \mathrm{~g}$ & $1.8 \mathrm{~g}$ & $274.28 \mathrm{~g}$ & $265.6 \mathrm{~g}$ \\
\hline
\end{tabular}

T1 (vermicast $6.5 \mathrm{t} / \mathrm{fed}$. + vermitea 4 times); T2 (vermicast $6.5 \mathrm{t} / \mathrm{fed}$. + vermitea 3 times); T3= (Vermicast $6.5 \mathrm{t} / \mathrm{fed}$.); T4 (Vermicast $3.5 \mathrm{t} / \mathrm{fed}$. + vermitea 4 times); T5 (Vermicast $3.5 \mathrm{t} /$ fed. + vermitea 3 times); T6 (Vermicast $3.5 \mathrm{t} / \mathrm{fed}$.) and T7 (Control = $\mathrm{R}_{100 \%}$ of chemical N, P and K fertilizers)

rate $(6.5 \mathrm{t} / \mathrm{fed}$.) of vermicompost and vermitea (4 times as a soil drench).In the same trend Al Ali et al. (2019), gave that organic applications had a significant $(\mathrm{p}<0.05)$ on eggplant yield and plant vegetation growth, so that the highest yield at organic fertilizers and the lowest total yield at chemical fertilizers. In the same line many researchers, (Seethalakshmi, 2011; Gandhi and Sundar, 2012; Sundararasu and Jeyasankar, 2014; Singh and Hussain, 2015 and Piya et al., 2018 and Bellitürk, 2018) reported that. They found the use of vermicompost improves the soil aggregates, bulk density, water holding capacity, organic matter, maro and micronutrients, microbial properties (enzymes and microbial population). Which reflected on development in early and latter stages of plant growth and the concentration applied of vermicompost must be got for optimum plant growth and quality. Regarding in Table (3) cleared that, significantly increased in anchocyanine in fruits at the high rate of vermicompost $(6.5 \mathrm{t} / \mathrm{fed}$. $)+4$ times of vermitea as a soil drench was $(516.6 \mathrm{mg} / \mathrm{g})$ in fruits as an average of both sites. Meanwhile the different all treatments were had significant differences between them of anthocyanin $(\mathrm{mg} / \mathrm{g})$ in fruits determined and the lowest significant means were ( 274.28 and $265.6 \mathrm{mg} / \mathrm{g}$, in two sites, respectively) in the treated plants with $\mathrm{R}_{\mathbf{1 0 0} \%}$ of NPK chemical fertilizer. Moreover, vermicast and vermitea have indirect effects on healthy plant growth through improving soil physical; chemical and biological properties caused ultimately enhance the vigorous eggplant growth and yield. Integration of vermicompost and vermitea as an organic liquid on the soil drench can be used as an alternative to chemical fertilizers and pesticides to produce healthy growth and quality eggplant fruits.

\section{CONCLUSION}

Effective response on the growth parameters, total fruit yield and quality of eggplant "cv. Black beauty" with addition of the high rate of vermicast $(6.5 \mathrm{t} / \mathrm{fed})+$. four times of vermitea as a soil irrigated as compared to using the huge chemical fertilizers \& pesticides.

\section{Future prospective}

Further this investigation intends to purify soils from chemicals pollution hazard. Raising kinds of earthworms to obtain vermicast and vermiwash, which they acted as (the mixture of organic fertilizer + biofertilizer + biopesticides), this mixture of them to obtain fertility and quality soils, safety food productivity and friendly cleaned environment.

\section{REFERENCES}

Adhikary, S. 2012. Vermicompost, the story of organic gold: A review. Agricultural Science. 3 (7):905- 917.

Aria, M., F. Monroy, and J. Dominguez.2006. Eisenia fetida activities fungal growth, triggering cellulose decomposition during vermicomposting. Microbial Ecology. 52: 738-746.

Alidadi, H., A.R. Safferi, D.Ketabi, R. Peiravi and A. Hosseinzadeh. 2014. Comparison of vermicompost and cow manure efficiency on the growth and yield of tomato plant. Health Scope. 3 (4): 1-5.

Adeleke, O., E.Ewemoje and A. Adedeji. 2015. Comparative analysis of pit composting and vermicomposting in a tropical environment. International J. of Biological, Mol. Agri. Biotech. Eng. 10: 45-57.

Al Ali, M., C. Gencoglan, and S.Gencoglan. 2019. The effect of organic and inorganic fertilizer applications on yield and plant vegetative growth of eggplant (Solanum melongena, L.). Int.J. of Plant \& Soil Sci. 29 (1): 1-9. 
Arancon, N. Q., C.A.Edwards, A.Babenko, J. Cannon and J.Metzger. 2008. Influences of vermicomposts, produced by earthworms and microorganisms from cattle manure, food waste and paper waste on the germination, growth and flowering of petunias in the greenhouse. Applied Soil Ecology. 39: 91- 99.

Arancon, N.Q., P. Galvis, C. Edwards and E. Yardim. 2003. The trophic diversity of nematodes communities in soil treated with vermicompost. Pedobiologia. 47: 736- 740.

Baniya, R. and G.S. Vaidya. 2011. Antifungal activity of actinomycetes from vermicompost and their morphological and biochemical characterization. Nepal J. of Sci. and Tech. 12: 97-102.

Brown, G.G. 1995. How do earthworms affect microfloral and faunal community diversity?. In Plant and Soil. 170: 209231.

Belliturk, K., S. Adiloglu, Y. Solmaz, A. Zahmacioglu and A. Adiloglu. 2017. Effects of increasing doses of vermicompost applications on $\mathrm{P}$ and $\mathrm{K}$ contents of pepper (Capsicum annuum, L.) and eggplant (Solanum melongena, L.). J. of Adv. Agric. Tech. 4(4):372- 375.

Bellitürk, K. 2018. Vermicomposting in Turkey: Challenges and opportunities in future. Eurasian J. of Forest Sci. 2018 6(4): 32-41.

Chaulagain, A., P.Dhurva, G.J. Lamichhane. 2017. Vermicompost and its role in plant growth promotion. Int. J. of Res. 4 (8): 849- 864.

Chapman, H.D. and P.F. Pratt. 1978. Methods of analysis for soil plant and waters. Univ. of California, Div. Agric. Sci., Priced public. 4043.

Evenhuis, B. 1978. Nitrogen determination. Dept. Agric. Res. Royal tropical inst. Amesterdam.

Jackson, M.L. 1973. Soil Chemical Analysis. Constable and Co. LTD. London.

Gandhi and U.S. Sundari. 2012. Effect of vermicompost prepared from aquatic weeds on growth and yield of eggplant (Solanum melongena, L.). Biofertilizers \& Biopesticides. 3(5): PP. $100-128$.

Lowther, G.R. 1980. Use of a single H2SO4 - H2O2 digest for the analysis of Pinus radiate needles. Common Soil Sci. Plant Analysis. 11: 175-188.

Landon, J.R. 1991. Booker tropical soil manual: A handbook for soil survey and agricultural and evaluation in the tropics and sub-tropics. Longman Scientific and Technical, Essex, New York. 474.

Musa, I.S., K.L. Njoku, C.C. Ndirib and F.M. Oke 2017. The effect of vermitea on the growth parameters of Spinacia oleracea, L. (Spinach). J. of Environmental Sci. and Pollution Research..3(4): 236-238.

Moraditochaee, M., H. R. Bozorgi and N. Halajisani. 2011. Effects of Vermicompost Application and Nitrogen Fertilizer Rates on Fruit Yield and Several Attributes of Eggplant (Solanum melongena L.) in Iran. World Applied Sci. J. 15 (2): 174-178.
Nath, G. D.K. S. and K. Singh. 2011. Productivity enhancement and nematode management through vermicompost and biopesticides in brinjal (Solanum melongena, L.). World Applied Sci. J. 12(4): 404-412.

Kumar, A. 2005. Verms and Vermitechnology, A.P.H. Publishing Corporation, New Delhi. 5 (71).

Klute, A. 1986. Methods of soil analysis part 1, 2 nd ed., Agron. Monor. GASA and SSSA, Madison, W.I.

Singh, R. S., S. Kumar, R. Gupta and R. Patil. 2008. Vermicompost substitution influence growth, physiological disorders, fruit yield and quality of strawberry. Int. J. Biol. Resour. Technol. 9: 507- 511.

Singh, C.A. and A. Hussain. 2015. Effect of vermicompost on growth, yield and quality of vegetable crops. Int. J. of Applied and Pure Sci. and Agri. 1-8 .

Singh, R., S.K. K. Soni, A. Awasthi and A.Kalra. 2012. Evaluation of vermicompost doses for management of root-rot disease complex in Coleus forskohlii under organic field conditions. Australasian Plant Pathology. 41: 397-403.

Singhai, P.K., B.K. Sarma and J.S. Srivastava. 2011. Biological management of commen scab of potato through Pseudomonas species and vermicompost. Biological Control. 57: 150-157.

Sinha, R.K., D. Valani, K. Chauhan and S. Agarwal. 2010. Embarking on a second green revolution for sustainable agriculture by vermiculture biotechnology using earthworms: J. of Agric. Biotech. And Sustain. Develop. 2.(7)113-128

Seethalakshmi, V.K.S. 2011. Response of eggplant to integrated nutrient management amended soil. Int. J. of Sci. \& Eng. Res. 2: (8): 1-8.

Sundararasu, K. and A. Jeyasankar. 2014. Effect of vermiwash on growth and yield of brinjal (Solanum melongena, L.). Asian J. of Sci. and Tech. 5(3): 171-173.

Statistical Analysis System. 2001. SAS/STAT Users' Guide for Personal Computers. Release 6.12, SAS Instt. Inc., Cary, N.C., SA. The national workshop for production and utilizing Biofertilizer Amman, Jordan,Arab Countries Union, Arab Agric. Dev. Org. 1988.

Soraya, I., C.Sulaiman, P. Mohamad. 2020. The Use of Vermiwash and Vermicompost Extract in Plant Disease and Pest Control. Natural Remedies for Pest, Disease and Weed Control. 187-201

Piya, S., I.Shrestha, P. Dhurva and J. Lamichhane. 2018. Vermicomposting in organic agriculture: Influence on the soil nutrients and plant growth. Int. J. of Res. 05(20): 1055- 1063. Page, A.L., R.H. Miller and D.R. Keeny. 1982. Methods of soil analysis. Amer. Soc. Agric. Inc., Madison.

Politud, R.E.R. and R.R. Pabellan. 2016. Efficacy of varying levels and brewing durations of vermitea foliar spray applications on the growth and yield of eggplant (Solanum melongena, L.). Int. J. of Scientific and Research Publications. 6(4) 488-496. 
Roods and Blood-Worth.1964. Roods, F.M. and M.E. BloodWorth.1964. Area measurement of cotton leaf by dry weight method, Agronomy J. 56 (5): 520-525.
Rabino, I., A. L. Mancinelli and K.H. Kuzmanoff. 1977. Photocontrol of anthocyanin synthesis VI. Spectral sensitivity, irradiance dependence and reciprocity relationship. Plant Physiol. 59: 569-573.

\section{الملخص العريي}

\section{كفاءة الاستجابة لمستويات الفيرمي كمبوست ،شاي الفيرمي علي نمو وإنتاج نبات الباذنجان الاسود}

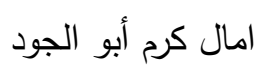

منوسط طول الثمرة ror, (سم- متوسط قطر الثرة سم- الوزن الجاف للمجموع الخضري r, 1101 اجم/ للنبات. كما أن إضافة أعلي مستوي من سماد الفيرمي كمبوست

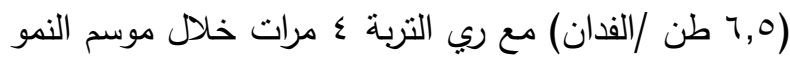
بشاي الفيرمي يؤدي لرفع جودة ثمار الباذنجان الاسود صنف المستورد حيث أن أعلي محتوي (cv. Black beauty)

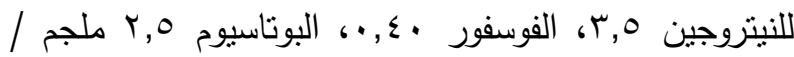
جم، الانثوسيانين 7,V 10 ملجم/جم في الثمار. كما أن أعلي

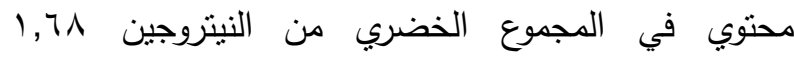

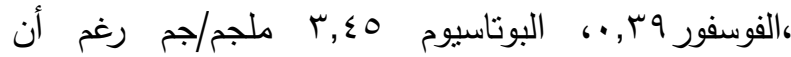
الانخفاض المعنوي للنمو الخضري ، الزهري ، الثمري في النباتات المعاملة بالكنترول(وهي إضافة الجرعات الموصي بها من الاسمدة الكيماوية) دون إضافة الاسمدة العضوية. الموصي بة من نتائج البحث إن إضافة سماد الفيرمي كمبوست بالجرعة العالية للاراضي المصرية الفقيرة (,0,7 طن / الفدان) مع ري التربة ء مرات بشاي الفيرمي خلالي موسم نمو النبات أدي لإنتاج نبات سليم خالي من الامراض لهاض

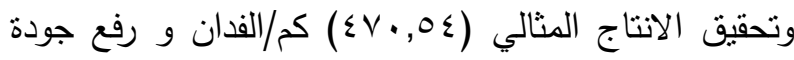
المنتج لنبات الباذنجان الاسود.
هدف الدراسة الحالية تحويل سبلة الدواجن ومخلفات المنازل إلي الفيرمي كمبوست لفوائدة العديدة حيث انة غني بالعناصر الكبري، الصغري، الهرمونات النباتية، المضادات الحيوية، العديد من الميكروبات النافعة الإنزيمات بإستخدام دودة الفيرمي'Eisenia foetide' .بلإضافة إلي إستخدام مستويين للفيرمي كمبوست المستوي العالي (0, اطن/ الفدان) والمستوي المنخفض (ه,r طن/ الفدان) مع ري التربة بشاي الفيرمي من r ألي ء مرات أو بدون ري و ذلك لزيادة إنتاج و جودة ثمار الباذنجان الاسود صنف (cv. Black beauty) المستورد بدون إستخدام الاسمدة الكيماوية. تم زراعة تجربتين حقليتين (بموقعين مختلفين) في مزرعة كلية الزراعة (ساباباشا) جامعة الاسكندرية لعام ر | • r.

أوضحت النتائج وضحت أن المستوي العالي لإضافة السماد العضوي(منتج الدود) الفيرمي كمبوست ال 7.0 طن/ الفدان مع ري التربة ء مرات بشاي الفيرمي لتحقيق الزيادة المعنوية لمعظم الصفات الخضرية ،الثمرية (أقصي إرتفاع

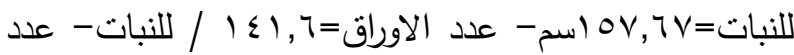
الافرع =9/ للنبات - مساحة سطح الورقة ^ץ, · سم -

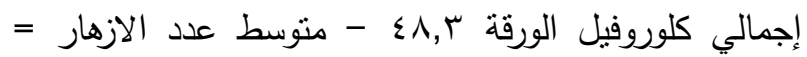

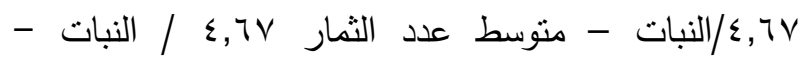

